\title{
Sustainable Grassland Management: An Exploratory Study of Progressive Ranchers in Nebraska
}

\author{
Stephanie M. Kennedy ${ }^{1}$, Mark E. Burbach ${ }^{1} \&$ Maggi S. Sliwinski ${ }^{1}$ \\ ${ }^{1}$ University of Nebraska-Lincoln, USA \\ Correspondence: Mark E. Burbach, University of Nebraska-Lincoln, USA. E-mail: mburbach@unl.edu
}

Received: February 28, 2016

Accepted: March 31, 2016 Online Published: April 11, 2016

doi:10.5539/sar.v5n2p103

URL: http://dx.doi.org/10.5539/sar.v5n2p103

\begin{abstract}
Well-managed grasslands provide numerous ecosystem services. Ranchers who employ sustainable grazing practices limit grassland conversion and conserve critical habitats. This phenomenological study explored the grassland management decisions of progressive ranchers in Nebraska. Each individual interviewed for this study is proactive about the state of their grasslands, whether they are motivated by financial or conservation factors. Throughout the evolution of their businesses, these ranchers have taken steps to improve their management techniques and continue to employ new strategies while planning for the long-term productivity of their grasslands. For policy makers and educators seeking to improve grassland management decisions, demonstrating new methods to be economical, promoting stewardship, and allowing for flexible implementation may increase acceptance of recommendations. Because progressive ranchers' livelihoods are connected to the land, and they are long-term goal oriented, they closely scrutinize, yet are open to advancing grassland management practices that benefit their cash flow, their pastures, their animals, and their families.
\end{abstract}

Keywords: grazing, grasslands, ranching, holistic, phenomenology, qualitative research

\section{Introduction}

Well managed grasslands provide numerous ecosystem services (biodiversity, water filtration along riparian buffers, carbon sequestration, and habitat for an array of plant and wildlife species), while providing an economic resource for ranchers (Vaisey \& Strankman, 1999). Ranching in a sustainable way provides food for a growing world population while simultaneously preserving an increasingly endangered habitat. Prior to European settlement, the North American Great Plains was dominated by perennial grasslands, and more than $95 \%$ of Nebraska was grassland (Johnsgard, 2005). Today, approximately $98 \%$ of the tallgrass prairie in Nebraska has been destroyed or degraded (Noss \& Peters, 1995; Samson \& Knopf, 1994; Samson, Knopf, \& Ostlie, 2004). Mixed grass and shortgrass prairies have fared only slightly better (Samson \& Knopf, 1994; Samson et al., 2004). One of the main drivers for habitat destruction in the U.S. is row crop agriculture (US Department of Agriculture [USDA], 2013; Wright \& Wimberly, 2013), with recent pressure to convert grasslands to cropland due to high returns for food and biofuel crops. Nebraska led the nation in the number of acres converted from non-cropland to cropland from 2011 to 2012: a total of 54,877 acres (USDA, 2013). Due to land use change and other factors, expanding annual row crop production can dramatically reduce the delivery of ecosystem services including diminished forage resources and habitat (Landis, Gardiner, van der Werf, \& Swinton, 2008; Power, 2010).

The fragmented nature of privately owned grasslands presents a challenge to habitat management (Hagen, Grisham, Boal, \& Haukos, 2013). Because over 97\% of Nebraska's land is privately owned (USDA, 2012a), voluntary private landowner participation in conservation programs is critical to conserving Nebraska's natural habitats (Powell, 2015). As economic pressures continue to increase, especially with regard to high corn prices, it is imperative to understand what factors influence landowners' decisions to maintain their grasslands rather than converting to crop production or any other non-range use. In order to ease some of the pressures placed upon remaining Nebraska grasslands, it is also important to understand what leads ranchers to adopt and maintain sustainable grazing methods and other conservation practices. Ranchers who employ sustainable grazing practices limit grassland conversion and conserve critical habitats.

Numerous studies have generally explored the characteristics that influence farmer conservation behaviors and decisions, but few have looked specifically at beef cattle producers (Sayre, 2004). Inconsistent predictors of 
farmer conservation include environmental awareness, attitudes, farm size, other household characteristics, and education (Baumgart-Getz, Prokopy, \& Floress, 2012; Kabii \& Horowitz, 2006; Knowler \& Bradshaw, 2007; Pannell et al., 2006; Prokopy, Floress, Klotthor-Weinkauf, \& Baumgart-Getz, 2008). However, there are few to no universal determinants of conservation behaviors among farmers (Prokopy et al., 2008; Barr \& Cary, 2000; Knowler \& Bradshaw, 2007). There also are mixed results regarding the impacts of financial incentives on conservation efforts; several studies illustrate the adoption of conservation practices because of financial interests as well as personal factors (Atkinson, Romsdahl, \& Hill., 2011; Barr \& Cary, 2000; Czap, Czap, Lynne, \& Burbach, 2015; Daley, Cobb, Bromley, \& Sorenson, 2004; Sheeder \& Lynne, 2011; Shulman \& Price, 2000; Troy et al., 2005).

One of the few studies of beef cattle producer conservation behaviors (Gillespie, Kim, \& Paudel, 2007) found that the two most common reasons for non-adoption among cattle producers were unfamiliarity and non-applicability (or perceived non-applicability) of the practice. Kennedy and Brunson (2007) surveyed and interviewed ranchers from a successful Colorado field school in regard to how they put new range management information into practice. They found that ranchers' primary motivations for management change are values tied to the land base (forage production, range health, water quality) as well as desire to improve profitability and having clearly defined goals - personal and management - encouraged change. They suggest framing outreach messages so they align with common ranch goals. Emphasizing the links between range management options and said goals may help initiate change. Similarly, Didier and Brunson (2004) interviewed Utah ranchers to better understand innovation adoption among range livestock operators. They found that innovation was related to ranching full-time, dependence on ranch income, anticipated future of the ranch, extent of social networks, and a desire to illustrate stewardship. Barriers included lack of time and resources along with peer influences and perceived drawbacks including perceptions about political/legal constraints. Roche, Cutts, Derner, Lubell, and Tate (2015) examined variables that influence the grazing strategy preference of Wyoming and California ranchers. They found that variables associated with ranchers' grazing preferences included a combination of human dimensions (goal setting, views on experiment and risk tolerance, information networks), ranch characteristics, and the ecoregions in which they lived. These authors assert that addressing the discrepancies between research and management will require substantive communication and participatory methods between researchers and ranchers. In another survey of beef cattle ranchers, Willcox, Giuliano, and Monroe (2012) examined intentions to consider wildlife management in routine cattle management activities. They found that attitudes and subjective norms best explained rancher intentions.

Since little is known about beef cattle producer conservation behaviors, Sayre (2004) contends that qualitative research, specifically, is necessary to increase our understanding of ranchers' grassland management because "existing studies using quantitative methods have found little correlation between ranchers' management practices and a variety of social factors" (p. 6). According to Creswell (2007), qualitative research is conducted when a problem or issue needs to be explored or because the researchers need a complex detailed understanding of the issue. Since the issue of conservation behaviors on the ranch is relatively unexplored, qualitative research is an appropriate place to start.

\section{Method}

\subsection{Research Design}

As noted above, the exploratory nature of this study favors a qualitative methodology. Merriam (2009) asserts, "Qualitative researchers are interested in understanding how people interpret their experiences, how they construct their worlds, and what meaning they attribute to their experiences" (p. 5). Correspondingly, applied research methodologist Creswell's working definition of qualitative research is as follows:

Qualitative research begins with assumptions, a worldview, the possible use of a theoretical lens, and the study of research problems inquiring into the meaning individuals or groups ascribe to a social or human problem. To study this problem, qualitative researchers use an emerging qualitative approach to inquiry, the collection of data in a natural setting sensitive to the people and places under study, and data analysis that is inductive and establishes patterns or themes. The final written report or presentation includes the voices of participants, the reflexivity of the researcher, and a complex description and interpretation of the problem, and it extends the literature or signals a call for action. (2007, p. 37)

Within the realm of qualitative methods, phenomenology was chosen as the research approach due to its focus on "first person reports of life experiences" (Moustakas, 1994, p. 84). In his synthesis of phenomenology Hustad (2015) explains:

Giorgi (2009) pointed to two guiding principles that not only serve to guide, but empower 
phenomenological research. The first insists that experiences must be described as they are presented, that is, nothing should be added or subtracted by an outside source. The second illuminates the role of free imaginative variation. In the pursuit of the essence of the experience, the researcher must expend energy exploring the characteristics of the phenomena, as he or she works to determine what is and is not essential. The benefits of using these two principles foster an approach to research characterized by both openness and rigor. (p. 64)

In order for our research to encompass both of the aforementioned guiding principles, we specifically selected an interpretative phenomenological approach (IPA), because:

[IPA] requires a combination of phenomenological and hermeneutic insights. It is phenomenological in attempting to get as close as possible to the personal experience of the participant, but recognizes that this inevitably becomes an interpretative endeavor for both participant and researcher. (Smith, Flowers, \& Larkin, 2009, p. 37)

Meaning is key to interpretative phenomenology. Because the goal is to understand the content of data rather than measure the frequency, IPA allows the researcher to have "an interpretative relationship with the transcript" (Smith \& Osborn, 2007, p. 66). This gives the researchers the flexibility to interpret and help make sense of what the participant is trying to get across.

This qualitative study explored progressive ranchers' grassland management decisions. The term "progressive", for use in this study, describes those ranchers who utilize conservation practices including holistic managing systems on their ranch, are innovative in their problem solving strategies, and use adaptive management strategies to deal with change. Our objectives are two-fold: first, to explore the impediments to sustainable grassland management practices, and second, to increase understanding about the beliefs, values, goals, and personality characteristics of beef cattle producers as related to grassland management. This study is guided by the overarching research question: What factors affect the grassland management decisions of progressive Nebraska ranchers?

\subsection{Participant Characteristics}

In the convention of qualitative designs, participants were selected based on their experience and knowledge of the central phenomenon of this study - ranching. The initial sampling pool of participants was selected from a rancher-mentoring program provided by the Nebraska Grazing Lands Coalition (NGLC) and producer members of the Nebraska Food Cooperative (NFC). Members of the NGLC were chosen due to the organization's mission to improve grazing lands in Nebraska and to employ holistic principles, and because those involved in the mentoring program have been nominated by their peers for successful work in conservation and stewardship. Rancher members from within the NFC who graze for the purpose of selling to niche markets (i.e. organic, grass fed and finished) were also included. With the help of a rangeland specialist, the list was then narrowed to select a diverse group of ranchers from varying locations around Nebraska that fit the definition of progressive used in this study. Participants were recruited through email requests and then called to set up meeting times and choice of location, all of which were held at their ranch. Interview length averaged one hour.

\subsection{Data Collection}

Semi-structured, face-to-face interviews were the primary method of data collection. A total of thirteen interviews were conducted with ranchers in Nebraska. Most of these interviews began with a tour of the ranch and some general conversation about their ranch management. Interview questions varied from broadly asking the ranchers about their life experiences in regard to their ranches and how they see the future of their ranches, to more specific questions regarding grazing management philosophy/goals, and pressures to convert their rangeland to cropland. Follow-up questions were asked via email or phone call.

\subsection{Data Analysis}

Smith, Flowers, and Larkin (2009) elaborate on the analytic process for an IPA study:

The analytic process here begins with the detailed examination of each case, but then cautiously moves to an examination of similarities and differences across the cases, so producing fine-grained accounts of patterns of meaning for participants reflecting upon a shared experience. In a good IPA study, it should be possible to parse the account both for shared themes, and for the distinctive voices and variations on those themes. (p. 38)

Each interview was audio recorded and then transcribed. Transcripts were then read multiple times with the margins utilized for annotating significant or interesting statements, which were selected not only on the basis of 
prevalence within the data, but also on richness. Emerging theme titles were then documented. Connections between the experiences of all of those interviewed led to a list of repeated themes. Each of the participants is represented in the superordinate themes (Smith \& Osborn, 2007). In conjunction with maintaining rigorous methods throughout the study, validity for this analysis was evaluated using peer review, an external audit of the coding process, and member checking (Creswell \& Miller, 2000).

\section{Results}

We found four major themes: 1) livelihoods are connected to the quality of the land;2) variability is the very nature of ranching; 3) ranching is an enjoyable way of life; and 4) stewardship is a calling. Subthemes were also included to better articulate findings and provide further clarification of the superordinate themes.

\subsection{Theme 1: Livelihoods Are Connected to the Quality of the Land}

The first important finding from speaking with these ranchers is that their livelihoods are connected to the quality of the land, so stewardship can be financially motivated. This is an important finding in grassland management decisions as well as conservation behaviors in general, as it illustrates that they are not dichotomous issues. Generating enough income to cover expenses or make a profit is not a separate and competing goal from managing the land in a sustainable manner; they are connected. This alignment between income and environmental condition affects these ranchers' decision-making and goals. As one rancher shared,

The good thing about ranching is... that profitability comes from managing our resources well. If you don't then it's going to deplete it and over long term that's bad. So we are fortunate that using our resources wisely is good for our business and good for profitability.

\subsubsection{Few Pressures from Commodities}

Accordingly, many ranchers recognized the need for good decisions that are based on "making it last over time". This repeatedly came up when discussing the question of converting their grass to cropland during years of high corn and soy prices. Most of these ranchers do not feel pressure from commodity prices for two reasons. First, not all land is arable. Ranchers who live in the Sandhills area of Nebraska mentioned that their land was not suitable for crops, only suitable for grazing. Even those with soils suitable for farming pointed out places on their land that are not appropriate for crops such as wetlands or low-land areas. Study participants consistently explained that they base their goals on the "big picture" and not the short-term fluctuations of the market. No one wants to be stuck selling low and buying high: many remember a time when corn was $\$ 1.50 /$ bushel, thus they are not going to base their decisions primarily on factors (such as the market) that are variable or cyclical in nature. The fluctuation of market prices was repeatedly mentioned during interviews.

One rancher reminded us that, "The markets can have a big effect on how you do things [regarding cattle], when you sell, how you feed, target weights, and everything that is involved around marketing." Markets do affect decisions within the context of grazing cattle, but, at least for this rancher, not whether to convert grassland to cropland. Another rancher thought that by the time he would till up the grass and have his land ready for crops, prices could be back down. Yet another mentioned not wanting to ruin all of the progress he had made with improving his grasslands, stating "maximizing profits on every acre" was not his goal. He said, "It certainly crosses my mind that right now we could make more money selling an $\$ 8$ bushel of corn on this highly productive land than we could graze it right now, but it goes back to looking at the long term and the big picture".

All study participants consider the long-term implications of their actions when making decisions. One grazier shared:

I am not just looking at the profitability of the ranch. Obviously that has to be a focus because if we are going to keep doing this sustainably it has to be economically feasible to do it, but it has to go beyond that. We want to manage our resources to the best of our ability.

The importance of the grasslands as a resource was mentioned several times throughout interviews. One rancher stated:

We are sitting on what I consider a pretty precious resource. One we could never, never put back is unbroken tallgrass prairie...we don't have an aquifer underneath us. I don't have an oil well...but our precious resource is our native tallgrass prairies. That is something we really want to protect, knowing that we are going to take some financial sacrifice to do it.

Similarly, another rancher shared that "It has always been a goal to not only get more from the land but to have the land on an improving range trend at the same time". Yet another individual said, "There is a good deal of 
satisfaction that goes with improving the land and making it better over time. I definitely consider myself a conservationist". Long-term goals, including conservation, help to outweigh the pressure of high price commodities.

\subsubsection{Working with the Natural Productivity of the Area (Holistic Ideas)}

Along with the idea of being a conservationist is the repeated idea of working with the natural productivity of an area. Many of the ranchers in this study specifically talked about having to work with nature or Mother Nature in order to be successful. When sharing his goals, one rancher explained, "...we are trying to just fit in with the environment. We are not out here trying to control Mother Nature... We try to coexist in a way that we can be profitable and not ruin the natural environment..." Another rancher also alluded to this balance. Regarding his grazing management philosophy, he shared that "It is kind of a balance between what is good for the grass, what is good for the soil and what is good for the animal". Similarly, another participant stated his ultimate goal is "to have our stocking rate meet our carrying capacity. ...We are always chasing it, we've got too many [cows] or we don't have enough depending upon rainfall and temperature, but our goal would be to find that level...."

When asked specifically about the kinds of variables that affect their grassland management decisions, Mother Nature was a prominent response. "Your best philosophies just go out the window when Mother Nature doesn't cooperate", shared one individual. On a list of these compiled elements, weather related factors were the most frequently reported: rain, moisture, precipitation, drought, weather, temperature, season, etc. One participant shared the uncontrollable factors that determine his actions:

There are two variables that affect my management decisions. They are temperature and moisture. There is a tremendous amount of decision made in all agriculture on two variables. Obviously those are external and you have absolutely no control over either one of them.

Responding similarly, another rancher shared:

Those management decisions are really based on the weather, time of year, the amount of rainfall, the amount of sunshine and temperature. That is really the fun part of being an organic farmer or sustainable farmer to me is that every day you have to visually inspect your farm and your animals and make a decision based on what the weather is today, how tall the grass is or is not today and how much rain do we get. [You have to be prepared to make that decision] every hour of the day.

As a consequence, these graziers are compelled to adapt their management strategies accordingly.

\subsection{Theme 2: Variability Is the Very Nature of Ranching}

"That is one of the things that makes ranching interesting. It is never the same from one year to the next. You just have to kinda get the pieces together to make it, to get the best results out of whatever is throwed at ya."

As the rancher's quote above suggests, and these ranchers' testimonies illustrate, variability is the very nature of ranching; nature is not static. With their jobs and livelihoods being centered on the natural environment, there is an acknowledged need for flexibility. These graziers assert that if Mother Nature does not work with you, you need to change your plan. One rancher mentioned that she and her father, "[very] rarely do things the same way every year...", which corresponds to this theme's title quote in which ranch management is likened to a puzzle - one that does not always fit together perfectly. Along the same lines, several of the ranchers who participated in this study specifically mentioned using holistic ideas or holistic management styles, which was described as "trying to keep all the pieces of the puzzle in mind as we operate". Or, more specifically:

To me the definition of a rancher would be somebody who [is] able to balance all of the parts and pieces of the ecosystem: the grass, the cows, the land. When do I need to be good to my land, when do I need to be good to my grass, and when do I need to be good to my cows - and try to balance those, where as much of the time as possible all three of them are being well taken care of...

In reflecting upon all of the areas in which a rancher has to be flexible, one participant stated:

There have been lots of changes every year. I think to stay successful we have to change all the time because prices changes, commodities change, land values change and our goals change and our age changes...I think when you quit changing then you need to turn it over to the next generation. 


\subsubsection{Always Looking for Ways to Improve}

For the reasons mentioned above, the ranchers interviewed in this study repeatedly mentioned learning from experience. Their philosophies and goals are constantly changing or evolving - the learning process is never done and as such, flexibility is key. One participant stated that his grazing management philosophy was to graze his cattle as long as he can without having to buy supplemental feeds. Another shared that he had taken some aspects he likes from several different grazing strategies and compiled them to make his own and he continues to do this, as his strategy is constantly evolving. He might use some things one year and hardly at all the next because techniques often depend upon the ecological context. Others mentioned changing their minds several times and needing to stay open-minded: "Never say never, or you may be eating your own words later". Overwhelmingly, these ranchers agree that they learn from each year's experiences and each year they get better. Fittingly, one participant said, "New ideas come up, whether from other ranches, the university, or even ourselves (what we might think and just to try new things) and that is how we learn and develop and become better land and grass managers".

While reflecting upon the evolution of their grazing practices, participants discussed several specific changes to their operations. Some of individuals talked about how their calving seasons have changed-how it just made more sense to work with the natural productivity of the area and match it up with the needs of the cow/calf. Specifically, this meant calving later in the season, trying to match the growth of the grass with the increased nutritional needs of the pregnant cows. One rancher mentioned the necessity of examining how many cows your grass could feed and basing decisions on that criterion. He believes in utilizing his own nutrients (hay) rather than having to purchase from outside sources, although during drought years this becomes difficult.

Another participant mentioned continually looking for better and different ways to do things. He also indicated that in the area in which he lives, there are several successful ranchers and all of them are doing things differently. He shared,

My grandfather, my great grandfather and my dad they took the knowledge and technology that was available to them at the time and I think they were all good land managers and ranch managers, but we have just tried to do it our way".

Flexibility is an important concept, especially with all of the change ranchers face.-

\subsection{Theme 3: Ranching Is an Enjoyable Way of Life}

"Because I couldn't think of anything else I would rather do"

There is just something about being a cowboy... "I don't know, there is just something internally... that says this is what you are meant to do", shared one rancher. He is not the only one who feels this way. Each of the individuals interviewed for this study thoroughly enjoys the ranching lifestyle. When asked why they ranch, many shared similar ideas. One individual "just can't see [himself] doing anything else"; there is "nothing else I'd rather do," commented another, while two more stated they had "always had a soft spot" or "passion" for it. There were also those who felt that ranching was a "calling" for them.

Overall, these ranchers acknowledged that ranching is hard work and that, "The physical energy it takes to manage rangeland is not something you can just automate...you just can't get beyond hands on". However, while ranching may be hard work, it is an enjoyable way of life. While most of these ranchers do a bit of farming alongside their cattle operations, several mentioned the monotony of farming and sitting in a tractor. "If I was just a crop farmer, it really takes a lot of heart and soul out of the farm", replied one individual. Another spoke about the debt of commodity farming, saying, "It is a normal procedure to have humongous overhead that is going to always be there. It is just a way of life". He does not prefer that way of life - to be at the mercy of the markets and bankers.

Grazing is currently meeting the needs of all individuals who participated in this study, including providing for their families and their own psychological/emotional needs. Among interviewees there was a recurring theme of job enjoyment and the need for fun. One participant explained this idea in detail:

It certainly is not for everybody. I think a lot of it has to do with I grew up ranching. I feel a small sense of obligation to maybe carry on the family tradition but at the same time it goes way beyond that. I enjoy working with nature and the kind of ranching I do allows me to be very creative. Holistic ranch management is what we follow and allows us to look at the big picture. I get to work with animals. I get to connect with the consumer. I get to be outside. I get to be my own boss and that is a big thing. 
Another shared this sense of enjoyment that comes from life on the ranch:

Well for me, I feel charged with a certain environmental responsibility. I feel that this ranch is one of the things I can do that not only can make money and live the lifestyle we have here is amazing, with the freedom and being our own boss-I mean that's amazing, but I feel that it is also a good thing what we are doing for the plants, and the $\mathrm{CO}_{2}$ and, and keeping this ground as close to nature as we can while still making money on it, that's important to me. I like that, that's really important to me.

There were other reasons given as to why these individuals ranch other than having freedom in "the great outdoors" or being a "country boy at heart", but the most frequent response went along the lines of "I was just meant to do it".

\subsubsection{Ranching Is a Family Business}

Part of the enjoyment that comes with ranching is that it is a family endeavor, as is illustrated by this quote:

My dad did [ranch], my granddad did. They all raised their families that way and they had some of the worst times and they had some of the best times and we are going through the same thing.

All but one of the study participants were born into a family of ranchers, and all of them have been involved on the ranch the majority of their lives. One grew up on a farm, but his love of livestock persuaded him to switch traditions when he became an adult. Accordingly, all of these individuals began ranch responsibilities during their childhood. Many of those who shared their experiences believe it was natural that they be involved in the family business. Illustrating this point, one stated, "We have always been in the cattle business - my great-grandfather, my grandfather, my dad...so it was kind of natural that I was going to have some interest in cattle and I did".

In discussing the history of their ranches, two participants specifically mentioned ancestors homesteading their ranches; another four mentioned being the fourth generation on the land they currently steward. One shared that his heirs will be the fifth generation to run this family business: "[We] are the fourth generation. We now have a fifth generation, my son and his wife, here on this end of the ranch that I now operate. My brother and his son-in-law and daughter operate what used to be the northern part of the ranch". This is a multi-family and multi-generational operation. Another mentioned his wife being the fifth generation; his kids being the sixth generation and grandkids the seventh generation. As these ranchers age, each of them mentioned the importance of ranch succession and of the thirteen interviewed, twelve planned (or hoped) for their children to take over, even those with young children. One stated, "I have three young kids that are involved in my ranching and to truly be sustainable in an operation like farming and ranching it has to go to the next generation".

These ranchers shared that the ranching lifestyle can be a great way to instill responsibility and reward into children. Two with young children discussed making chores and ranch life fun, so that it would be an enticing legacy to continue. "Work hard, play hard" was a motto mentioned. One rancher shared, "...for now my intention is to really try to do this in a way that we can build it that the future generations have that opportunity if they wish...." He emphasized not pressuring them, but making ranch life an enjoyable and interactive process in which the kids have a part in the decision-making process. He has told his daughter, "[y]ou can decide whether you want to keep growing your herd as you get into college. If you decide you don't like cattle and you want to go do something different you can just cash in your college fund and sell your cowherd".

While there is hope and preparation for future generations to take their place, these ranchers know it is not guaranteed, as interests vary among their heirs. The one rancher without a current successor shared that he had daughters, all of whom live in urban areas and have no interest in ranching. To that end, he and his wife will need to find someone to care for their land: "My wife and I are both really conscious to detail in all of our management, so we told each other it's going to be difficult to find somebody to manage it the way we have and would like to see that continue". He mentioned possible solutions, including specific lease agreements and working with interns who share similar management values. Another rancher, who is currently in the process of transitioning, shared, "I try to include my daughter and son-in-law in the business where we can carry on the operation to the next generation with responsibility; and try to treat people as I would like to be treated". He mentioned that it can be difficult for the older generation to let go, especially when they love the ranch life, but that age and health push the process along.

...[I]t doesn't matter who it is, every person has a different way to do stuff, and it's sometimes hard to watch somebody do it different than you do it. But that doesn't mean it's right or wrong. It doesn't mean 
I am right, and it doesn't mean that the next person is wrong. It is just different. What works for one person won't work for the other, and realizing that and accepting it and stuff, that is all part of the transition...

The phenomenon of ranch succession will be an important area of study in coming years, as the average age of farmers/ranchers is 57 (USDA, 2012b). In discussing this aging demographic at a New Farmer Forum in 2012, US Secretary of Agriculture Tom Vilsack said, "If left unchecked, this could threaten our ability to produce the food we need - and also result in the loss of tens of thousands of acres of working lands that we rely on to clean our air and water" (USDA, 2012b). It is important to ensure not only the future of food, but also the continued stewardship of grasslands.

\subsection{Theme 4: Stewardship Is a Calling.}

[I] think for the perception of ranching we need to do a great job of taking care of our resources and whether its water or its grass or its soil, you just have to continually work to make it better, and to me that is what the ultimate rancher is, it's to take care of what God's given you to have control of. I know there is the financial part and all that but that isn't, to me the satisfying part. [I] guess I've never been in it for the big bucks you know, I never have...

This theme overlaps with each of the previous ones, but it delves a bit deeper in illustrating the character of these ranchers. For them, stewardship is not just an enjoyable job; it is a calling. None of the participants in this study would trade this lifestyle. As the previous theme stated: there is nothing they would rather do. Ranching allows them the flexibility to be home when their children get off of the bus and to attend their children's sporting events. They are able to be independent, enjoy the outdoors, and work for themselves. Each person interviewed for this project very much enjoys animal husbandry. While not all of those interviewed consider themselves cowboys, there were a few who mentioned that aspect specifically, "Oh, I like to cowboy. I like to just be outside and I like animals, love to ride a horse."

In regard to their grassland management decisions, several of these individuals could be labeled as analytical: examining themselves and their practices frequently and changing when they thought it was necessary. Continual learning came up on several occasions. As previously discussed, constantly looking for ways to improve and trying new things are prevalent in this group. Whether it is joining pasture groups or talking with their neighbors, attending conferences, or searching the internet, most of these individuals do not assume to know it all and try not to "let [their] pride get in the way of [their] thought process". This helps them in remaining open minded. As such, one characterized himself as fearless while another mentioned not being afraid to take risks and make mistakes and has no problem asking for advice.

Stewardship was mentioned multiple times and there were multiple biblical references throughout the interviews. This was especially true when discussing what was special about their ranch or what their management philosophies were. Fittingly one participant stated, "We try to live by what the Good Book says; try to make it better every year". Later when sharing his philosophy he said:

$\mathrm{Oh}$, just pass it on to the next generation and be profitable and take care of the ground like it is supposed to be taken care of. Like the good Lord says, you are supposed to leave it in better shape than what it was when ya took it over, and this is kinda our philosophy and we want to pass it on to the next generations".

Similarly, one rancher concluded his interview with this:

You have to be thankful for one thing anytime you ever finish anything. It isn't me and it isn't you. That isn't my land. The good Lord does what He does and I know there are times I throw my hands up and wonder why in the devil $\mathrm{He}$ is doing what $\mathrm{He}$ is and lately that has been happening a lot. We do need to be real thankful for what we have and where we are at, and what we are doing and [having] the ability to do what we are doing, because $\mathrm{He}$ is the one that makes the decisions to whether we come and go or fail or succeed or whatever. So, if I had to end the story with anything I would have to say that we have got to be thankful for Him and what $\mathrm{He}$ has given us and what $\mathrm{He}$ is allowing us to do.

It is clearly important to these ranchers that they take good care of the soil, the grass, the animals, and their families.

\section{Discussion}

As the interviews with these progressive ranchers revealed, there are many factors internal and external to their 
operations that affect grassland management decisions. Nature or weather related variables appear to be the most recognized influences regarding decision-making. These factors are beyond individual control and require much flexibility in planning and goal setting. All of these ranchers base their grassland decisions on the "big picture" or "over the long-term" recognizing that what might make them a quick profit today may negatively influence their revenue stream in the future. Accordingly, managing the grass sustainably is understood to help the longevity and profitability of their businesses, so land quality is of the utmost importance. None of the ranchers interviewed for this study feel pressure to convert their pasture to cropland even with the recent price of corn and soy commodities. This is partly due to the areas in which some of them live, as the land is not arable, but also because some consider their land a valuable resource worth conserving. Several ranchers expressed lack of interest in full time farming as a deterrent to land conversion. Several farm part-time, although mostly as a complimentary business, but have no interest in full-time farm life. They very much enjoy their lifestyles as ranchers.

In this way, grazing systems are connected with desired lifestyle. While these ranchers "enjoy a challenge", do not mind hard work, and enjoy the outdoors and the freedom ranching allows, there is a personal diminishing return for their grazing system. They want to get the most out of their grassland and manage them to the best of their ability until it interrupts this desired lifestyle (i.e., does not allow for attending kids' sports games, being available after school, etc.). This is the main impediment to the adoption of more intensive management practices. In fact, each of the participants interviewed mentioned that they have intensified their grazing practices throughout the evolution of their ranch. They see it as profitable and good for the environment; there is merely a cut-off point when moving cows gets in the way of their life.

Although not mentioned specifically as an impediment to improved practices, many ranchers mentioned the increasing lack of mentorship available to them. Several mentioned former extension educators or grazing group leaders who had been integral to their current ways of thinking about grasslands and the way they make management decisions, but these mentors have since passed away and have not been replaced —or the positions have been filled, but now educators are responsible for several counties. Many of these ranchers continue to participate in social networking and attend conferences to stay up to date on information, but having someone in a mentor role to answer questions onsite is less frequent. Without someone to organize the group, there are fewer get-togethers. This leadership had been exceptionally valuable to these individuals and is certainly missed.

Decision making on the ranch is complicated and while the management decisions that these ranchers make are made in real time, each of them plans for the long term. Accordingly, each of the individuals interviewed for this project care about the state of their grasslands, whether motivated by financial or conservation factors. As mentioned above, all of these ranchers have taken steps to improve their management techniques and continue to employ new strategies.

Landowners will be more likely to change their grassland management in ways promoted by policy makers and educators if new methods can be shown to be economical, promote stewardship, and allow for flexible implementation. Because rancher livelihoods are connected to the land, and they are long-term goal oriented, they need to see how management recommendations or voluntary conservation programs will benefit their cash flow, their pastures, their animals, and their families.

\section{References}

Atkinson, L., Romsdahl, R., \& Hill, M. (2011). Future participation in the conservation reserve program in North Dakota. Great Plains Research, 21, 203-14.

Barr, N., \& Cary, J. (2000). Influencing improved natural resource management on farms. Canberra, ACT: Bureau of Rural Sciences.

Baumgart-Getz, A., Prokopy, L. S., \& Floress, K. (2012). Why farmers adopt best management practices in the United States: A meta-analysis of the adoption literature. Journal of Environmental Management, 96, 17-25. http://dx.doi.org/10.1016/j.jenvman.2011.10.006

Creswell, J., (2007). Qualitative inquiry and research design: Choosing among five approaches. Thousand Oaks, CA: Sage.

Creswell, J., \& Miller, D. (2000). Determining validity in qualitative inquiry. Theory into Practice, 39, 124-131. http://dx.doi.org/10.1207/s15430421tip3903_2

Czap, N. V., Czap, H. J., Lynne, G. D., \& Burbach, M. E. (2015). Walk in my shoes: Nudging for empathy conservation. Ecological Economics, 118, 147-158. http://dx.doi.org/10.1016/j.ecolecon.2015.07.010 
Daley, S. S., Cobb, D. T., Bromley, P. T., \& Sorenson, C. E. (2004). Landowner attitudes regarding wildlife management on private land in North Carolina. Wildlife Society Bulletin, 32, 209-219. http://dx.doi.org/10.2193/0091-7648(2004)32[209:LARWMO]2.0.CO;2

Didier, E. A., \& Brunson, M. E. (2004). Adoption of range management innovations by Utah ranchers. Journal of Range Management, 57, 330-336. http://dx.doi.org/10.2307/4003855

Gillespie, J., Kim, S., \& Paudel, K. (2007). Why don't producers adopt best management practices? An analysis of the beef cattle industry. Agricultural Economics, 36, 89-102. $\mathrm{http}: / / \mathrm{dx}$. doi.org/10.1111/j.1574-0862.2007.00179.x

Giorgi, A. (2009). The descriptive phenomenological method in psychology: A modified Husserlian approach. Pittsburgh, Pa: Duquesne University Press.

Hagen, C., Grisham, B., Boal, C., \& Haukos, D. (2013). A Meta-analysis of lesser prairie-chicken nest and brood-rearing habitats. Wildlife Society Bulletin, 37, 750-758. http://dx.doi.org/10.1002/wsb.313

Henderson, A. E., Reed, M., \& Davis, S. K. (2014). Voluntary stewardship and the Canadian Species at Risk Act: Exploring rancher willingness to support species at risk in the Canadian prairies, Human Dimensions of Wildlife: An International Journal, 19, 17-32. http://dx.doi.org/10.1080/10871209.2013.819595

Hustad, A. W. (2015). The cultural integration experience of Chinese immigrant teachers in the United States: An interpretative phenomenological analysis (unpublished doctoral dissertation). University of Nebraska, Lincoln.

Johnsgard, P. (2005). The nature of Nebraska: Ecology and biodiversity. University of Nebraska Press, Lincoln.

Kabii, T., \& Horowitz, P. (2006). A review of landholder motivations and determinants for participation in conservation covenanting programmes. Environmental Conservation, 33, 11-20. http://dx.doi.org/10.1017/S0376892906002761

Kennedy C. A., \& Brunson, M. W, (2007). Creating a culture of innovation in ranching: A study of outreach and $\begin{array}{llll}\text { cooperation } \quad \text { west-central } & \text { Colorado. } & \text { Rangelands, } & \text { 29(3), }\end{array}$ http://dx.doi.org/10.2111/1551-501X(2007)29[35:CACOII]2.0.CO;2

Knowler, D., \& Bradshaw, B. (2007). Farmers' adoption of conservation agriculture: A review and synthesis of recent research. Food Policy, 32, 25-48. http://dx.doi.org/10.1016/j.foodpol.2006.01.003

Landis, D. A, Gardiner, M. M., van der Werf, W., \& Swinton, S. M. (2008). Increasing corn for biofuel production reduces biocontrol services in agricultural landscapes. Proceedings of the National Academy of Sciences, 105, 20552-20557. http://dx.doi.org/10.1073/pnas.0804951106

Merriam, S. B. (2009). Qualitative Research: A guide to design and implementation. San Francisco, CA: Jossey-Bass.

Moustakas, C. (1994). Phenomenological research methods. Thousand Oaks, CA: Sage.

Noss, B. R. F., \& Peters, R. L. (1995). Endangered ecosystems: A status report on vanishing habitat and wildlife. Washington, DC: Defenders of Wildlife.

Pannell, D. J., Marshall, G. R., Barr, N., Curtis, A., Vanclay, F., \& Wilkinson, R. (2006). Understanding and promoting adoption of conservation practices by rural landholders. Australian Journal of Experimental Agriculture, 46, 1407-1424. http://dx.doi.org/10.1071/EA05037

Powell, L. A. (2015). Periodic corrections to agricultural land values provide opportunity for conservation. Journal of Soil and Water Conservation, 70,39A-44A. http://dx.doi.org/10.2489/jswc.70.2.39A

Power, A. G. (2010). Ecosystem services and agriculture: tradeoffs and synergies. Philosophical transactions of the Royal Society of London. Series B, Biological sciences, 365, 2959-2971. http://dx.doi.org/10.1098/rstb.2010.0143

Prokopy, L. S., Floress, K., Klotthor-Weinkauf, D., \& Baumgart-Getz, A. (2008). Determinants of agricultural best managment practice adoption: Evidence from the literature. Journal of Soil and Water Conservation, 63, 300-312. http://dx.doi.org/10.2489/jswc.63.5.300

Roche, L. M., Cutts, B. B., Derner, J. D., Lubell, M. N., \& Tate, K. W. (2015). On-ranch grazing strategies: Context for the rotational grazing dilemma. Rangeland Ecology \& Management, 68, 248-256. http://dx.doi.org/10.1016/j.rama.2015.03.011

Samson, F., \& Knopf, F. (1994). Prairie conservation in North America. BioScience, 44, 418-421. 
http://dx.doi.org/10.2307/1312365

Samson, F., Knopf, F., \& Ostlie, W. (2004). Great Plains ecosystems: Past, present, and future. Wildlife Society Bulletin, 32, 6-15. http://dx.doi.org/10.2193/0091-7648(2004)32[6:GPEPPA]2.0.CO;2

Sayre, N. F. (2004). Viewpoint: The need for qualitative research to understand ranch management. Rangeland $\begin{array}{llll}\text { Ecology } \quad \text { and } & \text { Management, }\end{array}$ http://dx.doi.org/10.2111/1551-5028(2004)057[0668:VTNFQR]2.0.CO;2

Sheeder, R., \& Lynne, G. D. (2011). Empathy-conditioned conservation: "Walking in the shoes of others" as a conservation farmer. Land Economics, 87, 433-452. http://dx.doi.org/10.3368/le.87.3.433

Shulman, A., \& Price, R. (2000). Case studies in increasing the adoption of sustainable practices. Canberra, ACT: Land and Water Resources Research and Development Corporation.

Smith, J., Flowers, P. \& Larkin, M. (2009). Interpretative Phenomenological Analysis. Thousand Oaks, CA: Sage Publications Inc.

Smith, J., \& Osborn, M., (2007). Interpretative phenomenological analysis. In Smith, J. (Ed.), Qualitative Psychology: A Practical Guide to Research Methods (pp. 53-81). Thousand Oaks: Sage, .

Troy, A. R., Strong, A. M., Bosworth, S. C., Donovan, T. M., Buckley, N. J., \& Wilson, M. L. (2005). Attitudes of Vermont dairy farmers regarding adoption of management practices for grassland songbirds. Wildlife Society Bulletin, 33, 528-538. http://dx.doi.org/10.2193/0091-7648(2005)33[528:AOVDFR]2.0.CO;2

US Department of Agriculture (USDA). (2012a). Nebraska NRCS year-end report. Retrieved from https://prod.nrcs.usda.gov/Internet/FSE_DOCUMENTS/nrcs142p2_027890.pdf

US Department of Agriculture (USDA). (2012b). Farm demographics. Retrieved from http://www.start2farm.gov/usda/knowledge

US Department of Agriculture (USDA). (2013). Cropland conversion. Retrieved from http://www.fsa.usda.gov/FSA/webapp?area=newsroom\&subject=landing\&topic=foi-er-fri-dtc.

Vaisey, J. S., \& Strankman, P. (1999). Prairie grasslands: An undervalued resource; Grass, cows and environmental management on the Canadian prairies. Great Plains Research, 9, 371-395.

Willcox, A. S., Giuliano, W. M., \& Monroe, M. C. (2012). Predicting cattle rancher wildlife management activities: An application of the theory of planned behavior. Human Dimenions of Wildlife, 17, 159-173. http://dx.doi.org/10.1080/10871209.2012.639043

Wright, C. K., \& Wimberly, M. C. (2013). Recent land use change in the Western Corn Belt threatens grasslands and wetlands. Proceedings of the National Academy of Sciences, 110, 4134-4139. http://dx.doi.org/10.1073/pnas.1215404110

\section{Copyrights}

Copyright for this article is retained by the author(s), with first publication rights granted to the journal.

This is an open-access article distributed under the terms and conditions of the Creative Commons Attribution license (http://creativecommons.org/licenses/by/3.0/). 